\title{
The Significance of Bacillus spp. in Disease Suppression and Growth Promotion of Field and Vegetable Crops
}

\author{
Dragana Miljaković $^{1, *(\mathbb{D} \text {, Jelena Marinković }}{ }^{1}$ and Svetlana Balešević-Tubić ${ }^{2}$ \\ 1 Department of Microbiological Preparations, Institute of Field and Vegetable Crops, Maksima Gorkog 30, \\ 21000 Novi Sad, Serbia; jelena.marinkovic@ifvcns.ns.ac.rs \\ 2 Soybean Department, Institute of Field and Vegetable Crops, Maksima Gorkog 30, 21000 Novi Sad, Serbia; \\ svetlana.tubic@ifvcns.ns.ac.rs \\ * Correspondence: dragana.bjelic@ifvens.ns.ac.rs
}

Received: 19 June 2020; Accepted: 10 July 2020; Published: 13 July 2020

\begin{abstract}
Bacillus spp. produce a variety of compounds involved in the biocontrol of plant pathogens and promotion of plant growth, which makes them potential candidates for most agricultural and biotechnological applications. Bacilli exhibit antagonistic activity by excreting extracellular metabolites such as antibiotics, cell wall hydrolases, and siderophores. Additionally, Bacillus spp. improve plant response to pathogen attack by triggering induced systemic resistance (ISR). Besides being the most promising biocontrol agents, Bacillus spp. promote plant growth via nitrogen fixation, phosphate solubilization, and phytohormone production. Antagonistic and plant growth-promoting strains of Bacillus spp. might be useful in formulating new preparations. Numerous studies of a wide range of plant species revealed a steady increase in the number of Bacillus spp. identified as potential biocontrol agents and plant growth promoters. Among different mechanisms of action, it remains unclear which individual or combined traits could be used as predictors in the selection of the best strains for crop productivity improvement. Due to numerous factors that influence the successful application of Bacillus spp., it is necessary to understand how different strains function in biological control and plant growth promotion, and distinctly define the factors that contribute to their more efficient use in the field.
\end{abstract}

Keywords: Bacillus; biocontrol agents; antibiotics; lytic enzymes; siderophores; induced systemic resistance; plant growth-promoting rhizobacteria

\section{Introduction}

Plant diseases, caused by various microorganisms, including fungi, bacteria, viruses, nematodes and protozoa, affect agricultural production and result in major yield losses [1]. Approximately 20-40\% of losses in crop yield are caused by pathogenic infections [2]. Different strategies have been used to reduce the occurrence of plant diseases including pesticides, less susceptible cultivars, crop rotation, and other control measures, but their efficacy is usually insufficient due to the survival and resistance of soil-borne pathogens [3]. Moreover, the excessive use of synthetic pesticides has adverse effects on the environment and living organisms, and also disturbs ecosystem functioning and decreases agricultural sustainability [4].

Nowadays, research is directed to environmentally friendly alternatives for controlling plant pathogens and improving crop production, which are recommended within an integrated crop management system (ICMS) [5]. As an important component of an ICMS, biological control is defined as the use of beneficial organisms to reduce the negative effects of plant pathogens and promote 
positive responses by the plant [6]. The most common approach to biological control is the selection of antagonistic microorganisms, studies on their mechanisms of action and development of a biocontrol preparation [7].

Bacillus species are among the most investigated biocontrol agents i.e., biopesticides which contribute to suppression of plant pathogens by antagonism and/or competition [8]. Inhibition of pathogen growth by Bacillus spp. entails the involvement of mechanisms such as competition for nutrients and space, production of antibiotics, hydrolytic enzymes, siderophores, and/or inducing systemic resistance [9]. Bacillus spp. also can act as biofertilizers or biostimulators, either by facilitating the uptake of certain nutrients from the environment (nitrogen fixation, phosphate solubilization), or by providing the plant with a compound (biosynthesis of plant hormones) [10].

Hence, Bacillus spp. represent an alternative to plant growth enhancement agrochemicals, i.e., synthetic pesticides and fertilizers. The beneficial effects of Bacillus spp. on plant growth and yield have been demonstrated in several agricultural crops including wheat, maize, soybean, sunflower, common bean, tomato, pepper, potato, cucumber, and many others [11]. Application of Bacillus spp. to increase the productivity of field and vegetable crops is limited by variability among the results obtained in the laboratory, greenhouse and field [12]. In fact, when reintroduced by plant/soil inoculation, only 1 to $2 \%$ of rhizobacteria exert a beneficial effect on plant growth [13]. Due to numerous factors that affect the effectiveness of Bacillus spp., it is necessary to understand how different strains deploy biocontrol and growth-promoting actions in plants, and clearly determine the traits and manner for selecting the best acting strains [12].

This review summarizes the different mechanisms utilized by Bacillus spp. in plant disease control and plant growth promotion, and focuses on the new approaches to the improvement of beneficial plant-Bacillus interactions and Bacillus spp. efficiency in the field.

\section{Genus Bacillus}

The genus Bacillus was established in 1872 by Cohn and encompasses over 200 described species and subspecies belonging to the Firmicutes phylum. Based on the morphological characteristics, bacteria of this genus are described as rod-shaped, Gram-positive, aerobic or facultatively anaerobic, and catalase-positive [14]. Due to their broad physiological ability and capability to form endospores, Bacillus spp. are resistant to adverse environmental conditions and omnipresent in a wide range of habitats, including soil. Bacillus spp. represent the predominant soil and rhizosphere bacteria, where they comprise up to 95\% of the Gram-positive bacterial populations [15]. Furthermore, they are among the most widespread endophytic bacteria [16].

Bacillus is a large and diverse group of non-pathogenic and pathogenic bacteria. Most species of Bacillus, as well as their products, are considered safe for intended use in the environment [17]. These bacteria are preferred for commercialization for their ability to secrete several bioactive metabolites, produce extremely tolerant endospores, and grow rapidly in different media [18]. Consequently, they maintain viability and can be easily formulated and stored [19]. Populations of Bacillus spp. can successfully persist in the soil and plant rhizosphere without any perdurable effects on other bacterial populations [20]. Commercial Bacillus-based preparations are developed and distributed worldwide and contain beneficial strains of Bacillus subtilis, Bacillus amyloliquefaciens, Bacillus pumilus, Bacillus licheniformis, Bacillus megaterium, Bacillus velezensis, Bacillus cereus, Bacillus thuringiensis, etc., [21].

\section{Mechanisms of Biological Control}

\subsection{Antibiotics}

The antagonistic activities of Bacillus spp. are frequently related to the production of secondary metabolites with antibiotic properties. These compounds mainly involve peptides with low molecular weight that are generated ribosomally (bacteriocins) or non-ribosomally (lipopeptides, peptides, polyketides). 
Bacteriocins are ribosomally synthesized peptides produced by numerous bacteria which might be useful against pathogenic and antibiotic-resistant bacteria [22]. Bacteriocins act against target cells by interfering with the synthesis of the cell wall or by forming pores in the cell membrane [23]. The antimicrobial mechanisms of bacteriocins are usually directed against the species which are the same or closely related to the producers, with a narrow spectrum of action. Nevertheless, due to the production of bacteriocins, Bacillus spp. exhibit a broad-spectrum of antibacterial activity [24]. Some reports identify bacteriocins and bacteriocin-like substances (BLSs) (amylolysin, amysin, subtilin, subtilosin A, subtilosin B, thuricin) isolated from various Bacillus spp., including B. amyloliquefaciens, B. subtilis, B. thuringiensis, B. cereus, and B. coagulans [25]. Isolation and characterization of bacteriocins and BLSs may have an important use in the biological control of the pathogenic bacteria. However, Bacillus spp., which produce non-ribosomally synthesized lipopeptides and peptides, exhibit much stronger antimicrobial activity [26].

Cyclic lipopeptides (LPs), well known for their antagonistic action against a wide range of plant pathogens, are the most thoroughly studied antibiotic compounds in Bacillus spp. [27]. These peptides are synthesized by large non-ribosomal peptide synthetases (NRPSs) [28]. The primary mechanisms of LPs' actions usually involve an interaction with the cell membrane of the target pathogens, causing changes in its structure and permeability through disruption, solubilization or formation of ion-conducting pores [26]. It has also been demonstrated that LPs interact with intracellular structures, such as DNA [29]. Recent investigations have shown that LPs influence colonization and persistence of Bacillus in the rhizosphere, and stimulate plant defense mechanisms [30].

The most important cyclic LPs from Bacillus spp. are represented by surfactin, iturin and fengycin families [27]. These antibiotics consist of amino acids, amino- or hydroxyl-fatty acids with different lengths of hydrocarbon chains. The surfactin family (surfactin, lichenysin, pumilacidin, halobacilin, bamilocyn) are heptapeptides, identified in B. subtilis, B. amyloliquefaciens, B. licheniformis, B. pumilus and Bacillus coagulans. Surfactins act as both antifungal and antibacterial agents. The iturin family (iturin, mycosubtilin, bacillomycin, bacillopeptins, mixirins, mojavensin, subtulene) consists of heptapeptides produced by B. subtilis, B. amyloliquefaciens, Bacillus circulans, B. pumilus, and Bacillus vallismortis. Iturins display inhibitory effects on a wide range of fungi, but are less active against bacteria. The fengycin family (fengycin, plipastatin, maltacin) are decapeptides of which production was detected in $B$. subtilis and B. amyloliquefaciens. Fengycins are useful in protecting plants against fungal pathogens [26-28].

Other non-ribosomally synthesized LPs include kurstakins, bacitracins, polymyxins, gramicidins, and tyrocidines. The kurstakins are cyclic or linear heptapeptides that are specific to the B. cereus and $B$. thuringiensis, with the ability to destabilize biological membranes of both bacteria and fungi [31]. Bacitracins are cyclic decapeptides produced by B. licheniformis, B. subtilis, and B. sonorensis, of which activity is primarily directed against Gram-positive bacteria [32]. Polymyxins are cyclic decapeptides produced by Paenibacillus polymyxa (Bacillus polymyxa), which inhibit Gram-negative bacterial cells. Gramicidins and tyrocidines are cyclic decapeptides produced by Bacillus brevis, active against a broad range of Gram-negative and Gram-positive bacteria [33].

Several Bacillus spp. are known to produce other non-ribosomally synthesized antibiotics, such as peptides (bacilysin, rhizocticin, amicoumacin, mycobacillin, diketopiperazines) and polyketides (bacillaene, dihydrobacillaene, difficidin, macrolactin), with diverse antifungal and antibacterial activities [34].

The most commonly used biocontrol agents, B. subtilis and B. amyloliquefaciens, dedicate 4-5\% and $8.5 \%$ of total genetic capacity to synthesis of secondary metabolites, with the potential to produce more than two dozen structurally diverse antimicrobial compounds $[27,35]$. Nowadays, gene clusters encoding for bacteriocins, as well as peptides and polyketides, can be readily identified in genomic sequences by genome mining. In total, 583 putative bacteriocin gene clusters were identified from 328 strains of 57 Bacillales species, while 1231 putative non-ribosomal antimicrobial gene clusters were detected and sub-grouped into 23 types of peptide and five types of polyketide compounds distributed over 49 species of Bacillales [36]. 
Numerous studies revealed a broad antimicrobial effect by Bacillus spp. due to production of antibiotics (Table 1). Bacillus spp. mostly produce LPs from one family, while a few strains were identified as co-producers of different LPs [37]. Furthermore, antimicrobial activity of Bacillus spp. relies on the proportion and diversity in the production of antibiotics [38]. Fusarium clove rot of garlic, as well as head blight of wheat, were successfully suppressed by $B$. subtilis and/or $B$. amyloliquefaciens, due to LPs production $[39,40]$. In another study, B. amyloliquefaciens was defined as a producer of bacteriocins, surfactin, and fengycin, and was proven as a very potent biocontrol agent against numerous Gram-positive and Gram-negative bacteria, as well as Fusarium oxysporum, Fusarium avenaceum, and Mucor sp. [24]. Ongena et al. [41] found that iturin and fengycin produced by B. subtilis, which contributed to antifungal activity against Pythium ultimum. Han et al. [30] showed that iturin-producing B. amyloliquefaciens was effective in the biocontrol of Verticillium dahliae. Similarly, lipopeptides from Bacillus sp. and B. amyloliquefaciens such as surfactin, iturin, and fengycin, were responsible for antifungal activity against Sclerotinia sclerotiorum [42]. When tested for its biocontrol potential, B. amyloliquefaciens and B. pumilus LPs producing strains were very effective in the reduction in Pseudomonas syringae pv. aptata infection of sugar beet [43]. Additionally, Yang et al. [44] established that B. subtilis was able to suppress Gaeumannomyces graminis var. tritici infection of wheat through the production of LPs, namely iturin, surfactin, plipastatin, bacillomycin, and difficidin. Antifungal lipopeptide produced by B. licheniformis, determined as surfactin, was very successful against Magnaporthe grisea, a causative agent of rice blast [45]. Antifungal activity against Rhizoctonia solani, Pythium aphanidermatum, and Sclerotium rolfsii was attributed to B. pumilus because of the production of lipopeptide pumilacidin from the surfactin family [46].

Table 1. Biocontrol mechanisms exhibited by Bacillus species.

\begin{tabular}{|c|c|c|c|c|}
\hline Bacillus Species & Mechanism (s) & Target Pathogen (s) & Plant Disease & Reference \\
\hline Bacillus amyloliquefaciens & $\begin{array}{l}\text { Bacteriocins, surfactin, } \\
\text { fengycin }\end{array}$ & $\begin{array}{l}\text { Various pathogenic bacteria, } \\
\text { Fusarium oxysporum, Fusarium } \\
\text { avenaceum, Mucor sp. }\end{array}$ & $\begin{array}{l}\text { Several diseases of } \\
\text { field and vegetable } \\
\text { crops }\end{array}$ & [24] \\
\hline Bacillus amyloliquefaciens & Iturin & Verticillium dahliae & Wilt of cotton & {$[30]$} \\
\hline $\begin{array}{c}\text { Bacillus } \\
\text { amyloliquefaciens/Bacillus } \\
\text { subtilis }\end{array}$ & $\begin{array}{l}\text { Iturin, surfactin/surfactin, } \\
\text { fengycin }\end{array}$ & Fusarium graminearum & Head blight of wheat & [39] \\
\hline Bacillus subtilis & Surfactin, Lytic enzymes & Fusarium spp. & Clove rot of garlic & [40] \\
\hline Bacillus subtilis & Iturin, fengycin & Pythium ultimum & Damping-off of bean & [41] \\
\hline $\begin{array}{l}\text { Bacillus sp., Bacillus } \\
\text { amyloliquefaciens }\end{array}$ & $\begin{array}{l}\text { Surfactin, iturin, fengycin, } \\
\text { siderophore }\end{array}$ & Sclerotinia sclerotiorum & $\begin{array}{l}\text { White mold of } \\
\text { common bean }\end{array}$ & [42] \\
\hline $\begin{array}{c}\text { Bacillus pumilus, Bacillus } \\
\text { amyloliquefaciens }\end{array}$ & Lipopeptides & Pseudomonas syringae pv. aptata & $\begin{array}{l}\text { Leaf spot disease of } \\
\text { sugar beet }\end{array}$ & [43] \\
\hline Bacillus licheniformis & Surfactin & Magnaporthe grisea & Blast disease of rice & [45] \\
\hline Bacillus subtilis & Chitinase & Rhizoctonia solani & $\begin{array}{l}\text { Stem canker and black } \\
\text { scurf of potato }\end{array}$ & [47] \\
\hline Bacillus amyloliquefaciens & Protease & $\begin{array}{l}\text { Fusarium oxysporum } \mathrm{f} . \mathrm{sp} \text {. } \\
\text { lycopersici }\end{array}$ & Wilt disease of tomato & [48] \\
\hline Bacillus amyloliquefaciens & $\begin{array}{c}\text { Siderophores, cellulase, } \\
\text { lipase, protease, chitinase }\end{array}$ & Clavibacter michiganensis & $\begin{array}{l}\text { Bacterial canker of } \\
\text { tomato }\end{array}$ & [49] \\
\hline Bacillus sp. & $\begin{array}{c}\text { Protease, glucanase, } \\
\text { chitinase, siderophores }\end{array}$ & Fusarium verticillioides & $\begin{array}{l}\text { Stalk and ear rot of } \\
\text { maize }\end{array}$ & {$[50]$} \\
\hline Bacillus velezensis & $\begin{array}{l}\text { Protease, Chitinase, } \\
\text { Cellulase, Glucanase }\end{array}$ & Botrytis cinerea & $\begin{array}{l}\text { Gray mold disease of } \\
\text { pepper }\end{array}$ & [51] \\
\hline
\end{tabular}




\subsection{Lytic Enzymes}

Antimicrobial activity of Bacillus spp. could also be due to the production of hydrolytic enzymes such as chitinases, chitosanases, glucanases, cellulases, lipases, and proteases, which efficiently hydrolyze the major components of the fungal and bacterial cell walls.

Chitinases (EC 3.2.1.14) are glycoside hydrolases (GHs) which degrade the $\beta$-1,4-glycosidic bonds in chitin, the second most abundant naturally available polysaccharide after cellulose, and the main component of the fungal cell wall [54]. Bacteria primarily produce chitinases in order to degrade chitin for its utilization as an energy source, whereas some bacterial chitinases are prospective biological control agents against a variety of plant diseases caused by phytopathogenic fungi [47,55]. Chitosanases (E.C. 3.2.1.132) are GHs which catalyze the hydrolytic degradation of the $\beta-1,4$-glycosidic bonds in the chitin derivative-chitosan [56]. Chitosanases are important for the extensive carbon and nitrogen recycle [57]. Since chitosan is also found in fungal cell walls, chitosanase-producing Bacillus spp. may be used as biocontrol agents to prevent plant infection caused by pathogens [58]. Glucanases are GHs which hydrolyze glycosidic bonds present in $\alpha$-glucans and $\beta$-glucans. $\alpha$-1,3-glucan is not indispensable cell wall component, but plays an important role in some fungi during cell separation and vegetative growth [59], while $\beta$-1,3-glucan is the second major component of the fungal cell wall after chitin [60]. The primary role of cell wall glucans in fungi is structural, but they may also be degraded and used as nutritional sources. Bacillus spp. are a rich source of $\alpha-1,3$-glucanase (EC 3.2.1.84) and $\beta$-1,3-glucanase (EC 3.2.1.39). The enzymes have previously been isolated from Bacillus brevis, B. licheniformis, B. subtilis, B. circulans, and Bacillus halodurans [61]. Besides chitin and glucan, the skeleton of fungal cell walls contains cellulose, lipids and proteins. Bacterial cellulases, lipases and proteases may, therefore, play a significant role in the cell wall lysis that occurs during pathogen-Bacillus interactions [48].

Successful cell wall degradation depends on the activity of more than one enzyme. Chitinase activity is preceded by, or coincides with, the hydrolytic activity of other enzymes, especially glucanases. Mixtures of hydrolytic enzymes with complementary modes of action may be required for maximum efficacy, while correct combinations of enzymes may increase antifungal activity [62].

Recently, several reports have documented the production of lytic enzymes from Bacillus spp. biocontrol agents (Table 1). Chitinase-producing B. subtilis was effective against Rhizoctonia solani [47]. Crude and purified protease of B. amyloliquefaciens showed efficacy in biocontrol of Fusarium oxysporum [48]. The potential of B. amyloliquefaciens for biocontrol of Clavibacter michiganensis ssp. michiganensis was attributed to the production of lytic enzymes (cellulase, lipase, protease, chitinase) [49]. Hydrolytic enzymes (protease, glucanase, chitinase) produced by Bacillus sp. were responsible for a strong inhibitory activity against Fusarium verticillioides causing stalk and ear rot of maize [50]. The strength of hydrolase activity (protease, chitinase, cellulase, glucanase) was the key factor of B. velezensis in control of pepper gray mold caused by Botrytis cinerea [51]. Generally, it has been found that strains of Bacillus spp. which have the ability to produce cell wall hydrolases are more effective in the suppression of plant pathogens [63]. In search of efficient biocontrol agents, isolation and characterization of enzyme-producing Bacillus spp. should be done in order to achieve maximum survival of bacteria under detrimental environmental conditions and intrusion of pathogens $[40,64]$.

\subsection{Siderophores}

Siderophores are metal-chelating, non-ribosomal peptides with low molecular weight produced by some microorganisms and plants, especially under iron starvation conditions [65]. Iron (Fe) is an essential element for different biological processes such as oxygen metabolism, DNA and RNA syntheses, electron transfer, and enzymatic processes. The primary role of siderophores is to chelate Fe, allowing its solubilization and extraction from minerals and organic compounds. The significance of siderophores in biological control is based on competition for Fe in order to reduce its availability for pathogens [9]. Furthermore, microbial siderophores can be reduced to donate Fe to the transport system of a plant or chelate Fe from soils, and then, do a ligand exchange with phytosiderophores, 
thus, providing plants with this essential element so as to enhance their growth [66]. In addition to Fe, siderophores also have the ability to bind a variety of metals in the environment, thereby acting as bioremediation agents [67].

Siderophores are grouped into three main families, depending on the functional group, including hydroxamates, catecholates, and carboxylates [9]. Most of the bacterial siderophores are catecholates, such as bacillibactin produced by several Bacillus spp. including B. subtilis, B. amyloliquefaciens, B. cereus, B. thuringiensis, etc., [68]. Besides bacillibactin, Bacillus spp. produce a wide variety of siderophores such as pyoverdine, pyochelin, schizokinen, petrobactin, etc., [69]. Bacillus spp. were better producers of siderophores than other bacterial isolates from the maize rhizosphere [70]. Siderophores produced by Bacillus spp. have been involved in suppression of several plant diseases (Table 1). For instance, siderophore-producing B. subtilis reduced the incidence of Fusarium wilt, and enhanced the growth and yield of pepper [52]. Several studies indicated synergistic antimicrobial effects of siderophores along with lipopeptides and/or lytic enzymes [42,49,50]. Similarly, B. subtilis is a promising biological control agent against Bipolaris sorokiniana due to production of siderophores, chitinase, and cellulase [53].

\section{Systemically Induced Disease Resistance}

Plants adapt to constant pathogen exposure through defense mechanisms. Resistance to pathogens, developed after proper stimulation, represents an improvement in the defense capacity of the plant. Infected plants increased their levels of signaling molecules which coordinate the activation genes for appropriate syntheses, followed by preventive structural and histological changes, preventative chemical substances (phenols and other products of secondary metabolism), and in other ways [71,72].

Plant defense mechanisms, such as induced systemic resistance (ISR), can be initiated by external agents before infection or triggered by a localized infection, resulting in systemic acquired resistance (SAR) [73]. Both biotic and abiotic factors have been used for inducing ISR in plants against different plant pathogens. ISR is promoted by non-pathogenic rhizobacteria, and is mostly dependent on the jasmonate (JA) and/or ethylene (ET) signaling pathways [74], while SAR is mediated via a salicylic acid (SA)-dependent process. SAR also activates specific sets of defense-related genes associated with the production of pathogenesis-related proteins (PR), while ISR is not accompanied by the activation of these genes [75]. The defense mediated by ISR is significantly weaker than that obtained by SAR. However, ISR and SAR together provide better protection, indicating that they can act additively in inducing resistance to pathogens [72].

Rhizobacteria promote ISR in plants through the production of various metabolites such as antibiotics, siderophores, volatile organic compounds (VOCs), and others [76]. Bacillus spp. are among the most studied rhizobacteria that trigger ISR in plants (Table 2), while being capable of inducing resistance against several pathogens in the same plant [77]. B. amyloliquefaciens induced salicylic acid-dependent resistance in tomato plants, reduced the incidence of Tomato spotted wilt virus, and delayed systemic accumulation of Potato virus $Y$ [78]. Application of B. cereus significantly reduced disease incidence caused by Botrytis cinerea through activation of ISR [79]. Chandler et al. [80] showed that $B$. subtilis triggered ISR in rice against Rhizoctonia solani via jasmonic acid (JA) and ethylene (ET), as well as abscisic acid (ABA) and auxin signaling. The same authors reported an indispensable role of $B$. subtilis LPs, namely fengycin and surfactin, in the induced defense state. ISR promoting B. amyloliquefaciens produced VOCs and significantly reduced spot disease caused by Xanthomonas axonopodis pv. vesicatoria in pepper [81]. The ability of B. megaterium to reduce Septoria tritici blotch severity, caused by Mycosphaerella graminicola, was the result of a combination of different mechanisms, including ISR [82]. Bacillus endophytes of maize may protect host plants by producing antifungal lipopeptides that inhibit Fusarium moniliforme as well as by inducing the systemic acquired resistance [83]. 
Table 2. Induced systemic resistance elicited by Bacillus species.

\begin{tabular}{|c|c|c|c|}
\hline Bacillus Species & Target Pathogen (s) & Plant Disease & Reference \\
\hline Bacillus amyloliquefaciens & $\begin{array}{c}\text { Tomato spotted wilt virus, } \\
\text { Potato virus } Y\end{array}$ & Wilt disease of tomato & [78] \\
\hline Bacillus cereus & Botrytis cinerea & $\begin{array}{l}\text { Gray mold disease of field and } \\
\text { vegetable crops }\end{array}$ & [79] \\
\hline Bacillus subtilis & Rhizoctonia solani & Sheath blight of rice & [80] \\
\hline Bacillus amyloliquefaciens & $\begin{array}{l}\text { Xanthomonas axonopodis } \\
\text { pv. vesicatoria }\end{array}$ & Leaf spot disease of pepper & [81] \\
\hline Bacillus megaterium & $\begin{array}{l}\text { Mycosphaerella } \\
\text { graminicola }\end{array}$ & Septoria tritici blotch of wheat & [82] \\
\hline Bacillus subtilis, Bacillus amyloliquefaciens & Fusarium moniliforme & Ear, stalk, and root rots of maize & [83] \\
\hline Bacillus subtilis & $\begin{array}{c}\text { Alternaria solani, } \\
\text { Phytophthora infestans }\end{array}$ & Early and late blight of tomato & [84] \\
\hline Bacillus spp. & Pyricularia oryzae & Blast disease of rice & [85] \\
\hline Bacillus sp. & Colletotrichum capsica & Anthracnose of chili & [86] \\
\hline Bacillus sp. & $\begin{array}{l}\text { Rhizoctonia solani, } \\
\text { Fusarium oxysporum }\end{array}$ & Root rot and wilt of soybean & [87] \\
\hline Bacillus subtilis & $\begin{array}{l}\text { Fusarium oxysporum f. sp. } \\
\text { cucumerinum }\end{array}$ & Root rot of cucumber & [88] \\
\hline Bacillus sp. & Plasmopara halstedii & Downy mildew of sunflower & [89] \\
\hline
\end{tabular}

Bacillus spp. can elicit ISR by inducing the synthesis of antioxidant defense enzymes. Host enzymes induced by B. subtilis include peroxidase (POX), polyphenol oxidase (PPO), phenylalanine ammonia-lyase (PAL), and superoxide dismutase (SOD). Increased synthesis of antioxidant defense enzymes results in ISR against early and late blight in tomato seedlings [84]. Similarly, Rais et al. [85] showed that Bacillus spp. enhanced the SOD, POX, PPO, and PAL activities in infected rice, thus, alleviating Pyricularia oryzae-induced oxidative damage and suppressing blast disease incidence. The antagonistic Bacillus sp. suppressed anthracnose disease of chili by the activation of defense-related enzymes and the accumulation of phenolic compounds [86]. Similarly, Bacillus sp. enhanced growth promotion and protection against Rhizoctonia solani and Fusarium oxysporum by the eliciting of defense-related enzymes (PAL, POX, PPO) in soybean [87], while B. subtilis was capable of impairing disease incidence, promoting seedling growth and increasing activities of antioxidant enzymes (POD, PPO, PAL) in cucumber plants [88]. The induction of resistance to Plasmopara halstedii by Bacillus sp. strain was accompanied by the accumulation of defense-related enzymes (PAL, POX, $\mathrm{PPO})$ in sunflower [89].

\section{Mechanisms of Plant Growth Promotion}

\subsection{Nutrient Availability}

Bacillus spp. produce numerous metabolites which can increase nutrient availability to plants, and thus, directly promote plant growth and yield. Most of the plant essential nutrients are supplied through mineral fertilization, a practice which causes major economic losses, as well as posing significant problems to the environment. The use of biofertilizers which contain $\mathrm{N}_{2}$-fixing and/or P-solubilizing Bacillus spp. is a reasonable approach to reducing the negative impacts of synthetic fertilizers without compromising food safety [5,17]. $\mathrm{N}_{2}$-fixing and P-solubilizing Bacillus spp. are directly related to nutrient uptake and the subsequent growth promotion in different plants (Table 3).

Nitrogen $(\mathrm{N})$ is essential for plant growth, albeit largely unavailable in its atmospheric form (more than $80 \%$ ) [90]. Biological nitrogen fixation (BNF) is carried out by several groups of microorganisms that are able to absorb elemental nitrogen from the atmosphere and form compounds, which serve as plant nutrients [91]. The microorganisms produce the enzyme nitrogenase in order to catalyze the 
conversion of molecular dinitrogen $\left(\mathrm{N}_{2}\right)$ to ammonia $\left(\mathrm{NH}_{3}\right)$, which is subsequently taken by plant roots and assimilated in amino acids. BNF provides Earth's ecosystems with about 200 million tons $\mathrm{N}$ per year [92]. The nitrogen-fixing microorganisms are either free-living or symbiotic. Several PGPR, including Bacillus spp. can decrease chemical fertilizer-N use and increase plant growth and yield through asymbiotic nitrogen fixation. BNF by rhizobacteria has been reported to contribute up to $12-70 \%$ of total $\mathrm{N}$ uptake in agricultural crops. The study of Kuan et al. [93] provided evidence that B. pumilus can fix atmospheric $\mathrm{N}_{2}$ and significantly increase the total $\mathrm{N}$ content and dry biomass of maize. Ding et al. [94] suggested that the nifH gene could be detected in both the Bacillus and Paenibacillus genera. Similarly, the study of Xie [95] reported nitrogenase activities of several Bacillus spp. including B. megaterium, B. cereus, B. pumilus, B. circulans, B. licheniformis, B. subtilis, B. brevis, and B. firmus. Szilagyi-Zecchin et al. [96] reported that endophytic Bacillus spp. were positive for the nitrogen fixation ability evaluated through the acetylene reduction assay and amplification of nifH gene. Increased relative abundance of Bacillus spp. in rice plants under the conditions of low nitrogen suggest the potential contribution of their BNF [97].

Table 3. Plant growth-promoting mechanisms exhibited by Bacillus species.

\begin{tabular}{|c|c|c|c|c|}
\hline Bacillus Species & Mechanism (s) & Treated Plant (s) & Effect & Reference \\
\hline Bacillus pumilus & $\mathrm{N}_{2}$-fixation & Maize & $\begin{array}{l}\text { Increase the total } \mathrm{N} \text { content and } \\
\text { dry biomass }\end{array}$ & [93] \\
\hline Bacillus sp. & $\mathrm{N}_{2}$-fixation & Maize & $\begin{array}{l}\text { Increased seed germination and } \\
\text { root volume }\end{array}$ & [96] \\
\hline $\begin{array}{l}\text { B. megaterium, } B \text {. } \\
\text { subtilis, } B \text {. simplex }\end{array}$ & P-solubilization & $\begin{array}{l}\text { Eggplant, pepper, } \\
\text { tomato }\end{array}$ & $\begin{array}{c}\text { Promoted seed germination and } \\
\text { vegetative growth }\end{array}$ & [98] \\
\hline Bacillus subtilis & P-solubilization & Cucumber & $\begin{array}{l}\text { Increased plant growth, total } \\
\text { accumulation of } \mathrm{P} \text { and } \mathrm{P} \text { uptake }\end{array}$ & [99] \\
\hline Bacillus subtilis & IAA, GA & Tomato & $\begin{array}{l}\text { Enhanced shoot and root } \\
\text { growth, seedling vigor and leaf } \\
\text { area, higher levels of hormones }\end{array}$ & {$[84]$} \\
\hline $\begin{array}{l}\text { Bacillus } \\
\text { methylotrophicus }\end{array}$ & GAs & Lettuce & $\begin{array}{l}\text { Increased shoot length, shoot } \\
\text { fresh weight, leaf width, } \\
\text { proteins, amino acids, macro } \\
\text { and micro minerals, carotenoids } \\
\text { and chlorophyll a }\end{array}$ & [100] \\
\hline Bacillus subtilis & CKs & Lettuce & $\begin{array}{l}\text { Increased plant shoot and root } \\
\text { weight, higher CKs levels }\end{array}$ & [101] \\
\hline Bacillus megaterium & CKs & Common bean & Promoted growth of seedlings & [102] \\
\hline Bacillus spp. & $\begin{array}{c}\text { IAA, CKs, GAs, } \\
\text { ABA }\end{array}$ & Soybean & $\begin{array}{l}\text { Better growth and higher } \\
\text { proline contents }\end{array}$ & [103] \\
\hline Bacillus subtilis & $\begin{array}{l}\text { IAA, ACC } \\
\text { deaminase }\end{array}$ & Tomato & $\begin{array}{l}\text { Increased shoot and root } \\
\text { biomass and chlorophyll (a and } \\
\text { b) contents }\end{array}$ & [104] \\
\hline Bacillus aryabhattai & $\begin{array}{c}\text { ABA, IAA, CKs, } \\
\text { GAs }\end{array}$ & Soybean & $\begin{array}{l}\text { Longer roots and shoots, higher } \\
\text { hormone levels, better stress } \\
\text { tolerance }\end{array}$ & [105] \\
\hline $\begin{array}{c}\text { Bacillus } \\
\text { amyloliquefaciens }\end{array}$ & $\mathrm{ABA}$ & Rice & $\begin{array}{c}\text { Increased growth and stress } \\
\text { tolerance }\end{array}$ & [106] \\
\hline
\end{tabular}

In addition to nitrogen, the plant growth directly depends on phosphorus (P). However, a high amount of $\mathrm{P}$ (more than $80 \%$ ) is fixed in soil and is unavailable for plant uptake due to adsorption, precipitation or conversion [107]. Microorganisms that dissolve organic and inorganic phosphates belong to the group designated as Phosphate Solubilization Microorganisms (PSM) [108]. These microorganisms solubilize insoluble inorganic P and mineralize insoluble organic P [109]. Mechanisms 
of inorganic phosphate solubilization by microorganisms involve the production of organic and inorganic acids, siderophores, protons, hydroxyl ions, and $\mathrm{CO}_{2}$, which chelate cations or reduce $\mathrm{pH}$ in order to release P [110]. Mineralization of organic phosphate occurs due to the synthesis of extracellular enzymes such as phosphatases, phytases, and phospholipases [111].

Plant/soil inoculation with PSM is a promising strategy for the enhancement of plant absorption of P, while Bacillus spp. are among the most powerful PSM. Saeid et al. [112] showed that solubilizing exudates produced by Bacillus (B. subtilis, B. megaterium, B. cereus) are composed of gluconic, lactic, acetic, and succinic acids, confirming strong correlation between the total concentrations of organic acids and the amounts of released phosphorus. Isolates of B. megaterium, B. subtilis, and B. simplex, exhibited P-solubilizing ability by producing acetic, propionic, isobutyric, isocaproic, caproic, and heptanoic acids, and had positive effects on the seed germination and vegetative growth parameters of eggplant, pepper, and tomato [98]. Tao et al. [113] suggested that P-solubilization and P-mineralization could coexist in the same Bacillus strain. Similarly, inoculation with B. subtilis increased plant growth, and total accumulation of $\mathrm{P}$ and $\mathrm{P}$ uptake by cucumber plants [99].

\subsection{Phytohormone Production}

Bacillus spp. may directly increase plant yield through mechanisms that impart the production of phytohormones or plant growth regulators (PGRs), such as auxins, cytokinins, gibberellins, ethylene, and abscisic acid. Plant hormones are organic substances that influence the physiology and development of plants at very low concentrations. Plant hormone biosynthesis by Bacillus spp. has been directly related to subsequent growth promotion in different plants (Table 3).

Auxins are a group of plant hormones that stimulate plant growth, mainly through the regulation of cell division, cell elongation, and tissue differentiation. The main naturally occurring auxin is indole-3-acetic acid (IAA) [114]. Different bacteria, including Bacillus spp., have the ability to produce IAA and use this phytohormone to interact with plants as part of their colonization strategy, including phytostimulation and circumvention of basal plant defense mechanisms [80]. Production of IAA is widespread among soil bacteria, and approximately $80 \%$ of rhizobacteria have been estimated to produce IAA [115]. The in vitro application of IAA-producing Bacillus strains on plant roots resulted in increases in root length as well as the number of lateral roots [116]. B. subtilis was reported to enhance shoot and root growth, seedling vigor and leaf area of tomato, while higher levels of gibberellins and IAA were detected in treated plants [84]. Recent studies demonstrated that Bacillus spp. play a major role in controlling endogenous IAA levels in plant roots by regulating the auxin-responsive genes, thereby causing changes in root architecture [117].

Gibberellins (GAs) are a group of plant hormones that affect many developmental processes in higher plants, including seed germination, stem elongation, flowering, and fruiting. Gutierrez-Manero et al. [118] documented the production of gibberellins by B. pumilus and B. licheniformis. The beneficial effect of Bacillus methylotrophicus on plants due to the secretion of an array of gibberellins was confirmed by increasing the percentage of seed germination of lettuce, muskmelon, soybean, and vegetable mustard [100]. The same authors established that GA-producing bacterial strain increased shoot length, shoot fresh weight, leaf width, proteins, amino acids, macro and micro minerals, carotenoids and chlorophyll in lettuce.

Cytokinins (CKs) are a group of plant hormones that play a key role in promoting cell division, or cytokinesis, in plant roots and shoots. They are important regulators of other physiological and developmental plant processes such as seed germination, apical dominance, nutrient mobilization, and leaf senescence. Plants and microorganisms produce about 30 compounds from the group of CKs. It has been found that $90 \%$ of phosphate-dissolving rhizobacteria have the ability to produce CKs in vitro [119]. Arkhipova et al. [101] reported the ability of B. subtilis to produce CKs, while inoculation of lettuce plants increased the cytokinin content of both shoots and roots, as well as plant shoot and root weight. Ortíz-Castro et al. [102] reported that B. megaterium promoted the growth of Arabidopsis 
thaliana and Phaseolus vulgaris seedlings through CKs production. Naz et al. [103] also perceived that cytokinin-producing species, such as Bacillus and others, stimulated the growth of soybean plants.

Ethylene is a gaseous plant hormone that mainly regulates maturation and senescence processes, as well as response to biotic and abiotic stresses. In addition to plants, ethylene production was established in bacteria and fungi, but little has been reported on how ethylene-producing microorganisms affect plant growth. Several PGPR, including Bacillus spp., synthesize the enzyme 1-aminocyclopropane-1-carboxylate (ACC) deaminase that modulates ethylene levels in plants which might otherwise become growth inhibitory [120]. The enzyme ACC deaminase (3.5.99.7) cleaves ACC (direct precursor of ethylene biosynthesis in plants) into ammonia and $\alpha$-ketobutyrate. Bacteria characterized by ACC deaminase activity can help maintain plant growth and development under stress conditions (drought, salt, flooding and anoxia, the presence of pathogens or contaminants) [121]. The interaction of plants with ACC deaminase-producing bacteria may be expected to promote plant growth during plant processes associated with local increase in ethylene concentration, like flower wilting or symbiosis establishment [122]. Although ACC deaminase activity has been described in many Bacillus strains [104,123], ACC deaminase genes (structural gene acdS and the regulatory gene $a c d R$ ) could not be identified in 271 completely sequenced strains belonging to the Bacilli class, including many soil and plant-associated Bacillus and Paenibacillus species [124].

Abscisic acid (ABA) is a plant hormone with an important role in many plant physiological processes, including seed germination and stress tolerance. Park et al. [105] showed that Bacillus aryabhattai produced significant amounts of ABA, IAA, CKs, and GAs in culture, while inoculated soybean plants had high levels of phytohormones, longer roots and shoots, and better tolerance to heat, oxidative, and nitrosative stress. The bacterial endophyte B. amyloliquefaciens has been found to produce ABA and increase plant growth and resistance to salinity stress [106].

\section{Efficient Use and New Approaches}

\subsection{Isolation and Identification}

Prior to characterization and selection in laboratory and in greenhouse/field conditions, the search for effective strains requires isolation and identification of preferred Bacillus species from different sources. Bacillus spp. are the predominant soil, rhizosphere and endophytic bacteria $[15,16]$. Considering a very small proportion of beneficial microorganisms in the rhizosphere, their isolation, multiplication, and inoculation into the plant/soil trigger microbiological processes and intensify overall microbial activity [70]. Thus, only a few Bacillus spp. of about 200 within the genus exhibit multiple plant growth-promoting traits and might be useful in formulating inoculants [21]. Identification of isolated Bacillus spp. is of great importance because their beneficial traits are characteristic of certain species. Accordingly, it is necessary to use methods that can quickly and reliably test a large number of Bacillus spp. as the potential plant growth promoters and biological control agents.

Determination of morphological, physiological and biochemical traits is a long and often unreliable process. The most accurate method for examining the diversity of Bacillus spp. is their identification and characterization at the molecular level. The NCBI (National Center for Biotechnology Information) and RDP (Ribosomal Database Project) databases contain 2611 individual 16S rDNA sequences originating from 175 different species of Bacillus, of which only 1586 have been identified to the species level [125]. In addition to standard molecular methods such as $16 \mathrm{~S}$ rRNA analysis, RFLP (Restriction Fragment Length Polymorphism), RAPD (Random Amplified Polymorphic DNA), rep-PCR (Repetitive element sequence-based Polymerase Chain Reaction), MLSA (Multilocus Sequence Analysis), etc., different PCR methods with species-specific primers are increasingly used for reliable differentiation of Bacillus spp. [126]. 


\subsection{Characterization and Selection}

The characterization of bacteria includes determination of numerous traits in laboratory, while selection of potential biofertilizers and biopesticides involves testing their effectiveness on the plant-soil system in greenhouse and/or field. The tests require a lot of time, which makes it impossible to examine a large number of strains. Given that no individual or combined traits can reliably predict the effectiveness in biocontrol and plant growth promotion, Akinrinlola et al. [90] suggested greenhouse pot tests as the first criterion for bacterial strain selection, instead of screening bacteria for multiple traits. According to reports, the effectiveness of Bacillus spp. frequently varies depending on specific plant and soil conditions, which can constrain their ability to colonize the rhizosphere and express beneficial traits [12].

The efficiency of inoculation is usually higher when bacteria are isolated from the rhizosphere of plant species, and/or soil that will be inoculated, suggesting that the growth-promoting ability of the strains is highly related to certain plant species and soil types [12]. Furthermore, the efficiency of Bacillus spp. from the rhizosphere is higher compared to those from the bulk soil, while both the rhizosphere and endophytic bacteria possess various beneficial traits regarding the number and the production amount of these characteristics [127]. Knowledge of biocontrol and plant growth promotion mechanisms of Bacillus spp. is very important for their intended use, for instance, the use of LPs and hydrolase-producing strains in the suppression of pathogen infection, or P-solubilizing and $\mathrm{N}_{2}$-fixing strains in $\mathrm{P}$ and $\mathrm{N}$-deficient soils. Their efficiency as individual and combined plant/soil inoculants in different environments needs to be established through continuous selection of effective isolates in greenhouse and field trials.

\subsection{Plant-Bacillus Interactions}

Successful application of Bacillus spp. in the field also depends on plant-Bacillus interactions and it can be limited by poor colonization of the rhizosphere [128]. Bacillus spp. require $24 \mathrm{~h}$ to form a biofilm, which contributes to root colonization of Bacillus spp. and extends their beneficial effects in the soil [129]. Transcriptomic analysis of the B. amyloliquefaciens genome revealed numerous genes included in rhizosphere habituation and plant-beneficial traits, such as plant polysaccharide utilization, cell motility and chemotaxis, secondary antibiotics synthesis, and plant growth promotion-relevant clusters [130]. Gao et al. [128] demonstrated that both chemotaxis and swarming motility are important in tomato root colonization by B. subtilis, while the part of swarming is greater than that of chemotaxis.

However, root colonization is more effectual in indigenous strains of Bacillus than in laboratory or commercial strains. Emerging strategies such as microbiome engineering and breeding of microbe-optimized crops can directly or indirectly detect, modulate and enhance the traits and ways for better performance of Bacillus strains [3,18]. The genes involved in root colonization and plant-Bacillus interactions, are induced by the presence of root and seed exudates [129-131]. New research in plant-bacteria interactions uncovers plant capability to shape their rhizosphere and endorhiza microbiome [127]. Recent studies of the rhizobiome and the utilization of next-generation sequencing (NGS) techniques, combined with proteomics, metagenomics, metabolomics, etc., will assist to elaborate on these interactions, including how this relationship affects plant health and growth [132].

\subsection{Bacillus-Based Preparations}

In recent years, the distribution of commercial Bacillus-based preparations has significantly increased worldwide (Table 4). In addition to their beneficial influence on plants, effective strains of Bacillus spp. should be able to persist in the environment and be stable and viable for extended storage and purposeful use in the field. Resistance and stability are among the major limitations of Bacillus-based preparations. These bacteria are suitable for commercialization due to their ability to secrete various metabolites, produce endospores, and grow rapidly in different media [17-20]. 
Endospores of Bacillus spp. can not only endure adverse environmental conditions but survive all processing phases during production. In order to enhance sporulation and synthesis of preferable metabolites, production of Bacillus-based preparations should be optimized at each stage, which implies selection of appropriate strains or consortium of strains, as well as cultivation and formulation process [133].

Table 4. Examples of commercial Bacillus-based preparations.

\begin{tabular}{|c|c|c|c|}
\hline Bacillus Species & Preparation & Plant (s) & Company \\
\hline Bacillus subtilis & Serenade ${ }^{\circledR}$ & Vegetables, fruits & AgraQuest Inc., USA \\
\hline Bacillus subtilis & Companion $^{\circledR}$ & $\begin{array}{l}\text { Legumes, vegetables, maize, } \\
\text { and others }\end{array}$ & Growth Products Ltd., USA \\
\hline Bacillus subtilis & Kodiak $^{\circledR}$ & Legumes, cotton, and others & Gustafson Inc., USA \\
\hline Bacillus subtilis & Cease ${ }^{\circledR}$ & Several crops & BioWorks Inc., USA \\
\hline Bacillus subtilis & Subtilex ${ }^{\circledR}$ & $\begin{array}{l}\text { Vegetables, legumes, cotton, } \\
\text { and others }\end{array}$ & $\begin{array}{l}\text { Becker Underwood, Inc., } \\
\text { USA }\end{array}$ \\
\hline Bacillus subtilis & Pro-Mix ${ }^{\circledR}$ & Soybean, ornamentals, and others & $\begin{array}{c}\text { Premier Horticulture Inc., } \\
\text { Canada }\end{array}$ \\
\hline Bacillus subtilis & FZB24 ${ }^{\circledR}$ & Several crops & ABiTEP GmbH, Germany \\
\hline Bacillus subtilis & Bio Safe $^{\circledR}$ & Legumes, vegetables, cotton & $\begin{array}{l}\text { Lab. Biocontrole } \\
\text { Farroupilha, Brazil }\end{array}$ \\
\hline Bacillus subtilis & Ecoshot $^{\circledR}$ & $\begin{array}{l}\text { Vegetables, legumes, fruits, } \\
\text { and others }\end{array}$ & $\begin{array}{l}\text { Kumiai Chemical Industry, } \\
\text { Japan }\end{array}$ \\
\hline Bacillus subtilis & Biosubtilin ${ }^{\circledR}$ & $\begin{array}{l}\text { Cereals, vegetables, legumes, } \\
\text { oilseeds, cotton, and others }\end{array}$ & $\begin{array}{c}\text { Biotech International Ltd., } \\
\text { India }\end{array}$ \\
\hline $\begin{array}{c}\text { Bacillus } \\
\text { amyloliquefaciens }\end{array}$ & BioYield $^{\circledR}$ & Legumes, vegetables, tobacco & Gustafson Inc., USA \\
\hline $\begin{array}{c}\text { Bacillus } \\
\text { amyloliquefaciens }\end{array}$ & Rhizocell GC ${ }^{\circledR}$ & Cereals, sugar beet & $\begin{array}{c}\text { Lallemand Plant Care, } \\
\text { France }\end{array}$ \\
\hline $\begin{array}{c}\text { Bacillus } \\
\text { amyloliquefaciens }\end{array}$ & $\begin{array}{c}\text { RhizoVital }{ }^{\circledR} 42, \\
\text { RhizoVital }^{\circledR} 42 \mathrm{~TB}\end{array}$ & Vegetables, cereals, ornamentals & ABiTEP GmbH, Germany \\
\hline Bacillus pumilus & Ballad $^{\circledR}$ Plus & $\begin{array}{l}\text { Cereals, oilseeds, sugar beet, } \\
\text { sweet corn }\end{array}$ & AgraQuest Inc., USA \\
\hline Bacillus pumilus & Yield Shield ${ }^{\circledR}$ & $\begin{array}{l}\text { Legumes, cereals, vegetables, } \\
\text { sugar beet, cotton }\end{array}$ & Bayer CropScience, USA \\
\hline Bacillus pumilus & Sonata ${ }^{\circledR}$ & Vegetables, fruits & AgraQuest Inc., USA \\
\hline Bacilluslicheniformis & EcoGuard $^{\circledR}$ & Several crops & $\begin{array}{c}\text { Novozymes A/S Denmark, } \\
\text { Novozymes Biologicals, } \\
\text { USA }\end{array}$ \\
\hline Bacillus velezensis & Botrybel $^{\circledR}$ & Vegetables, fruits & Agricaldes, Spain \\
\hline Bacillus megaterium & Symbion- $\mathrm{P}^{\circledR}$ & $\begin{array}{c}\text { Cereals, legumes, oilseeds, } \\
\text { vegetables }\end{array}$ & T. Stanes \& Co. Ltd., India \\
\hline Bacillus sp. & Sublic ${ }^{\circledR}$ & Several crops & ELEP Biotechnologies, Italy \\
\hline Bacillus spp. & Bacillus SPP ${ }^{\circledR}$ & Several crops & Bio Insumos Nativa, Chile \\
\hline
\end{tabular}

Selection of appropriate Bacillus strains must be performed so as to avoid competition, especially if a preparation contains more than one species. For instance, interspecies competition between biofilms of the soil-residing bacteria B. subtilis and related Bacillus species could negatively affect their formulation and efficient use [134]. Nutrient sources such as carbon, nitrogen, inorganic salts and additional substances, as well as environmental factors such as temperature, $\mathrm{pH}$ value and $\mathrm{O}_{2}$ supply, influence growth in addition to the production of spores and metabolites in Bacillus species [135]. Bacillus spp. are suitable for preparation as either solid or liquid formulations, with the addition of different carriers, stabilizers, protectants and other supplements [133]. Further research should find 
the best possible production technology for each bacterial strain or bacterial combination, while taking into account the cost-effectiveness of Bacillus-based products.

\section{Conclusions}

Bacillus spp. represent an environmentally friendly strategy for crop production improvement through different mechanisms of biological control, biofertilization and biostimulation. Although possibilities to use Bacillus spp. for disease incidence reduction and crop production improvement are well known, their application is not a widespread practice, mostly because of inconsistent efficiency under different conditions. The ability of Bacillus spp. to exhibit beneficial traits depends on the interaction of bacteria with plant and/or pathogen, and the environment. Given the great economic and ecological importance of Bacillus spp., it is necessary to increase the number of practically important species and find advanced methods for their rapid and comprehensive research and efficient application.

Author Contributions: Writing—original draft preparation, D.M.; writing—review and editing, D.M., J.M. and S.B.-T. All authors have read and agreed to the published version of the manuscript.

Funding: This research was supported by the Ministry of Education, Science and Technological Development of the Republic of Serbia, grant number: 451-03-68/2020-14/200032.

Conflicts of Interest: The authors declare no conflict of interest.

\section{References}

1. Chakraborty, S.; Newton, A.C. Climate change, plant diseases and food security: An overview. Plant Pathol. 2011, 60, 2-14. [CrossRef]

2. Savary, S.; Ficke, A.; Aubertot, J.; Hollier, C. Crop losses due to diseases and their implications for global food production losses and food security. Food Secur. 2012, 4, 519-537. [CrossRef]

3. Syed Ab Rahman, S.F.; Singh, E.; Pieterse, C.M.J.; Schenk, P.M. Emerging microbial biocontrol strategies for plant pathogens. Plant Sci. 2018, 267, 102-111. [CrossRef]

4. Aktar, W.; Sengupta, D.; Chowdhury, A. Impact of pesticides use in agriculture: Their benefits and hazards. Interdiscip. Toxicol. 2009, 2, 1-12. [CrossRef]

5. Souza, R.; Ambrosini, A.; Passaglia, L.M.P. Plant growth-promoting bacteria as inoculants in agricultural soils. Genet. Mol. Biol. 2015, 38, 401-419. [CrossRef] [PubMed]

6. Lazarovits, G.; Turnbull, A.; Johnston-Monje, D. Plant Health Management: Biological Control of Plant Pathogens. In Encyclopedia of Agriculture and Food Systems; Van Alfen, N.K., Ed.; Academic Press: London, UK, 2014; Volume 4, pp. 388-399.

7. Alabouvette, C.; Olivain, C.; Steinberg, C. Biological control of plant diseases: The European situation. Eur. J. Plant Pathol. 2006, 114, 329-341. [CrossRef]

8. Mnif, I.; Ghribi, D. Potential of bacterial derived biopesticides in pest management. Crop Prot. 2015, 77, 52-64. [CrossRef]

9. Beneduzi, A.; Ambrosini, A.; Passaglia, L.M.P. Plant growth-promoting rhizobacteria (PGPR): Their potential as antagonists and biocontrol agents. Genet. Mol. Biol. 2012, 4, 1044-1051. [CrossRef]

10. Borriss, R. Use of Plant-Associated Bacillus Strains as Biofertilizers and Biocontrol Agents in Agriculture. In Bacteria in Agrobiology: Plant Growth Responses; Maheshwari, D.K., Ed.; Springer: Berlin/Heidelberg, Germany, 2011; pp. 41-76.

11. Aloo, B.N.; Makumba, B.A.; Mbega, E.R. The potential of Bacilli rhizobacteria for sustainable crop production and environmental sustainability. Microbiol. Res. 2019, 219, 26-39. [CrossRef]

12. Mrkovački, N.; Bjelić, D. Plant growth promoting rhizobacteria (PGPR) and their effect on maize. Ratar. I Povrt. 2011, 48, 305-312. [CrossRef]

13. Antoun, H.; Kloepper, J.W. Plant Growth Promoting Rhizobacteria. In Encyclopedia of Genetics; Brenner, S., Miller, J.H., Eds.; Academic Press: New York, NY, USA, 2001; pp. 1477-1480.

14. Logan, N.A.; De Vos, P. Genus Bacillus. In Bergey's Manual of Systematic Bacteriology, 2nd ed.; De Vos, P., Garrity, G.M., Jones, D., Krieg, N.R., Ludwig, W., Rainey, F.A., Schleifer, K.H., Whitman, W.B., Eds.; Springer: Dordrecht, The Netherlands; Berlin/Heidelberg, Germany; London, UK; New York, NY, USA, 2009; Volume 3 , pp. 21-128. 
15. Prashar, P.; Kapoor, N.; Sachdeva, S. Rhizosphere: Its structure, bacterial diversity and significance. Rev. Environ. Sci. Biotechnol. 2013, 13, 63-77. [CrossRef]

16. De Silva, N.I.; Brooks, S.; Lumyong, S.; Hyde, K.D. Use of endophytes as biocontrol agents. Fungal Biol. Rev. 2019, 33, 133148. [CrossRef]

17. Bhattacharyya, P.N.; Goswami, M.P.; Bhattacharyya, L.H. Perspective of beneficial microbes in agriculture under changing climatic scenario: A review. J. Phytol. 2016, 8, 26-41. [CrossRef]

18. Wu, L.; Wu, H.-J.; Qiao, J.; Gao, X.; Borriss, R. Novel routes for improving biocontrol activity of Bacillus based bioinoculants. Front. Microbiol. 2015, 6, 1395. [CrossRef] [PubMed]

19. Czaja, K.; Góralczyk, K.; Struciński, P.; Hernik, A.; Korcz, W.; Minorczyk, M.; Łyczewska, M.; Ludwicki, J.K. Biopesticides-towards increased consumer safety in the European Union. Pest Manag. Sci. 2015, 71, 3-6.

20. Radhakrishnan, R.; Hashem, A.; Abd Allah, E.F. Bacillus: A biological tool for crop improvement through bio-molecular changes in adverse environments. Front. Physiol. 2017, 8, 667. [CrossRef]

21. Mazzola, M.; Freilich, S. Prospects for biological soilborne disease control: Application of indigenous versus synthetic microbiomes. Phytopathology 2017, 107, 256-263.

22. Zou, J.; Jiang, H.; Cheng, H.; Fang, J.; Huang, G. Strategies for screening, purification and characterization of bacteriocins. Int. J. Biol. Macromol. 2018, 117, 781-789. [CrossRef]

23. Juturu, V.; Wu, J.C. Microbial production of bacteriocins: Latest research development and applications. Biotechnol. Adv. 2018, 36, 2187-2200. [CrossRef]

24. Salazar, F.; Ortiz, A.; Sansinenea, E. Characterisation of two novel bacteriocin-like substances produced by Bacillus amyloliquefaciens ELI149 with broad-spectrum antimicrobial activity. J. Glob. Antimicrob. Resist. 2017, 11, 177-182. [CrossRef]

25. Abriouel, H.; Franz, C.M.A.P.; Omar, N.B.; Gálvez, A. Diversity and applications of Bacillus bacteriocins. FEMS Microbiol. Rev. 2011, 35, 201-232. [CrossRef] [PubMed]

26. Fira, D.J.; Dimkić, I.; Berić, T.; Lozo, J.; Stanković, S. Biological control of plant pathogens by Bacillus species. J. Biotechnol. 2018, 285, 44-55. [CrossRef] [PubMed]

27. Stein, T. Bacillus subtilis antibiotics: Structures, synthesis and specific functions. Mol. Microbiol. 2005, 56, 845-857. [CrossRef] [PubMed]

28. Cawoy, H.; Debois, D.; Franzil, L.; De Pauw, E.; Thonart, P.; Ongena, M. Lipopeptides as main ingredients for inhibition of fungal phytopathogens by Bacillus subtilis/amyloliquefaciens. Microb. Biotechnol. 2015, 8, 281-295. [CrossRef] [PubMed]

29. Zhang, B.; Dong, C.; Shang, Q.; Han, Y.; Li, P. New insights into membrane-active action in plasma membrane offungal hyphae by the lipopeptide antibiotic bacillomycin L. Biochim. Biophys. Acta Biomembr. 2013, 1828, 2230-2237. [CrossRef]

30. Han, Q.; Wu, F.; Wang, X.; Qi, H.; Shi, L.; Ren, A.; Liu, Q.; Zhao, M.; Tang, C. The bacterial lipopeptide iturins induce Verticillium dahliae cell death by affecting fungal signaling pathways and mediate plant defence responses involved in pathogen-associated molecular pattern-triggered immunity. Environ. Microb. 2015, 17, 1166-1188. [CrossRef]

31. Gélis-Jeanvoine, S.; Canette, A.; Gohar, M.; Caradec, T.; Lemy, C.; Gominet, M.; Jacques, P.; Lereclus, D.; Slamti, L. Genetic and functional analyses of krs, a locus encoding kurstakin, a lipopeptide produced by Bacillus thuringiensis. Res. Microbiol. 2017, 168, 356-368. [CrossRef] [PubMed]

32. Adimpong, D.B.; Sørensen, K.I.; Thorsen, L.; Stuer-Lauridsen, B.; Abdelgadir, W.S.; Nielsen, D.S.; Derkx, P.M.F.; Jespersen, L. Antimicrobial susceptibility of Bacillus strains isolated from primary starters for African traditional bread production and characterization of the bacitracin operon and bacitracin biosynthesis. Appl. Environ. Microbiol. 2012, 78, 7903-7914. [CrossRef] [PubMed]

33. Wan, Y.; Stanovych, A.; Gori, D.; Zirah, S.; Kouklovsky, C.; Alezra, V. $\beta, \gamma$-diamino acids as building blocks for new analogues of Gramicidin S: Synthesis and biological activity. Eur. J. Med. Chem. 2018, 149, 122-128. [CrossRef] [PubMed]

34. Wang, T.; Liang, Y.; Wu, M.; Chen, Z.; Lin, J.; Yang, L. Natural products from Bacillus subtilis with antimicrobial properties. Chin. J. Chem. Eng. 2015, 23, 744-754. [CrossRef]

35. Chen, X.H.; Koumoutsi, A.; Scholz, R.; Schneider, K.; Vater, J.; Süssmuth, R.; Piel, J.; Borriss, R. Genome analysis of Bacillus amyloliquefaciens FZB42 reveals its potential for biocontrol of plant pathogens. J. Biotechnol. 2009, 140, 27-37. [CrossRef] 
36. Zhao, X.; Kuipers, O.P. Identification and classification of known and putative antimicrobial compounds produced by a wide variety of Bacillales species. BMC Genom. 2016, 17, 882. [CrossRef]

37. Ongena, M.; Jacques, P. Bacillus lipopeptides: Versatile weapons for plant disease biocontrol. Trends Microbiol. 2008, 16, 115-125. [CrossRef]

38. Meena, K.R.; Kanwar, S.S. Lipopeptides as the antifungal and antibacterial agents: Applications in food safety and therapeutics. Biomed Res. Int. 2015, 2015, 473050. [CrossRef] [PubMed]

39. Zalila-Kolsi, I.; Mahmoud, A.B.; Ali, H.; Sellami, S.; Nasfi, Z.; Tounsi, S.; Jamoussi, K. Antagonist effects of Bacillus spp. strains against Fusarium graminearum for protection of durum wheat (Triticum turgidum L. subsp. durum). Microbiol. Res. 2016, 192, 148-158. [CrossRef] [PubMed]

40. Bjelić, D.; Ignjatov, M.; Marinković, J.; Milošević, D.; Nikolić, Z.; Gvozdanović-Varga, J.; Karaman, M. Bacillus isolates as potential biocontrol agents of Fusarium clove rot of garlic. Zemdirbyste 2018, 105, 369-376. [CrossRef]

41. Ongena, M.; Jacques, P.; Touré, Y.; Destain, J.; Jabrane, A.; Thonart, P. Involvement of fengycin-type lipopeptides in the multifaceted biocontrol potential of Bacillus subtilis. Appl. Microbiol. Biotechnol. 2005, 69, 29-38. [CrossRef]

42. Sabaté, D.C.; Pérez Brandan, C.; Petroselli, G.; Erra-Balsells, R.; Audisio, M.C. Biocontrol of Sclerotinia sclerotiorum (Lib.) de Bary on common bean by native lipopeptide-producer Bacillus strains. Microbiol. Res. 2018, 211, 21-30. [CrossRef]

43. Nikolić, I.; Berić, T.; Dimkić, I.; Popović, T.; Lozo, J.; Fira, D.; Stanković, S. Biological control of Pseudomonas syringae pv. aptata on sugar beet with Bacillus pumilus SS-10.7 and Bacillus amyloliquefaciens (SS-12.6 and SS-38.4) strains. J. Appl. Microbiol. 2019, 126, 165-176. [CrossRef] [PubMed]

44. Yang, L.; Han, X.; Zhang, F.; Goodwin, P.H.; Yang, Y.; Li, J.; Xia, M.; Sun, R.; Jia, B.; Zhang, J.; et al. Screening Bacillus species as biological control agents of Gaeumannomyces graminis var. tritici on wheat. Biol. Control 2018, 118, 1-9. [CrossRef]

45. Tendulkar, S.R.; Saikumari, Y.K.; Patel, V.; Raghotama, S.; Munshi, T.K.; Balaram, P.; Chattoo, B.B. Isolation, purification and characterization of an antifungal molecule produced by Bacillus licheniformis BC98, and its effect on phytopathogen Magnaporthe grisea. J. Appl. Microbiol. 2007, 103, 2331-2339. [CrossRef]

46. De Melo, F.M.P.D.; Fiore, M.F.; Moraes, L.A.B.D.; Silva-Stenico, M.E.; Scramin, S.; Teixeira, M.D.A.; Melo, I.S.D. Antifungal compound produced by the cassava endophyte Bacillus pumilus MAIIIM4A. Sci. Agric. 2009, 66, 583-592. [CrossRef]

47. Saber, W.I.; Ghoneem, K.M.; Al-Askar, A.A.; Rashad, Y.M.; Ali, A.A.; Rashad, E.M. Chitinase production by Bacillus subtilis ATCC 11774 and its effect on biocontrol of Rhizoctonia diseases of potato. Acta Biol. Hung. 2015, 66, 436-448. [CrossRef] [PubMed]

48. Guleria, S.; Walia, A.; Chauhan, A.; Shirkot, C.K. Molecular characterization of alkaline protease of Bacillus amyloliquefaciens SP1 involved in biocontrol of Fusarium oxysporum. Int. J. Food Microbiol. 2016, 232, 134-143. [CrossRef] [PubMed]

49. Gautam, S.; Chauhan, A.; Sharma, R.; Sehgal, R.; Shirkot, C.K. Potential of Bacillus amyloliquefaciens for biocontrol of bacterial canker of tomato incited by Clavibacter michiganensis ssp. michiganensis. Microb. Pathog. 2019, 130, 196-203. [CrossRef]

50. Douriet-Gámez, N.R.; Maldonado-Mendoza, I.E.; Ibarra-Laclette, E.; Blom, J.; Calderón-Vázquez, C.L. Genomic analysis of Bacillus sp. strain b25, a biocontrol agent of maize pathogen Fusarium verticillioides. Curr. Microbiol. 2018, 75, 247-255. [CrossRef]

51. Jiang, C.-H.; Liao, M.-J.; Wang, H.-K.; Zheng, M.-Z.; Xu, J.-J.; Guo, J.-H. Bacillus velezensis a potential and efficient biocontrol agent in control of pepper gray mold caused by Botrytis cinerea. Biol. Control 2018, 126, 147-157. [CrossRef]

52. Yu, X.; Ai, C.; Xin, L.; Zhou, G. The siderophore-producing bacterium, Bacillus subtilis CAS15, has a biocontrol effect on Fusarium wilt and promotes the growth of pepper. Eur. J. Soil Biol. 2011, 47, 138-145. [CrossRef]

53. Villa-Rodríguez, E.; Parra-Cota, F.; Castro-Longoria, E.; López-Cervantes, J.; de los Santos-Villalobos, S. Bacillus subtilis TE3: A promising biological control agent against Bipolaris sorokiniana, the causal agent of spot blotch in wheat (Triticum turgidum L. subsp. durum). Biol. Control 2019, 132, 135-143. [CrossRef]

54. Rathore, A.S.; Gupta, R.D. Chitinases from bacteria to human: Properties, applications, and future perspectives. Enzyme Res. 2015, 2015, 791907. [CrossRef] 
55. Kumar, M.; Brar, A.; Yadav, M.; Chawade, A.; Vivekanand, V.; Pareek, N. Chitinases-Potential candidates for enhanced plant resistance towards fungal pathogens. Agriculture 2018, 8, 88. [CrossRef]

56. Weikert, T.; Niehues, A.; Cord-Landwehr, S.; Hellmann, M.J.; Moerschbacher, B.M. Reassessment of chitosanase substrate specificities and classification. Nat. Commun. 2017, 8, 1698. [CrossRef] [PubMed]

57. Choi, Y.J.; Kim, E.J.; Piao, Z.; Yun, Y.C.; Shin, Y.C. Purification and characterization of chitosanase from Bacillus sp. strain KCTC 0377BP and its application for the production of chitosan oligosaccharides. Appl. Environ. Microbiol. 2014, 70, 4522-4531. [CrossRef]

58. Seo, D.J.; Lee, J.H.; Song, Y.S.; Park, R.D.; Jung, W.J. Expression patterns of chitinase and chitosanase produced from Bacillus cereus in suppression of phytopathogen. Microb. Pathog. 2014, 73, 31-36. [CrossRef]

59. Suyotha, W.; Yano, S.; Wakayama, M. $\alpha-1,3-$ Glucanase: Present situation and prospect of research. World J. Microbiol. Biotechnol. 2016, 32, 30. [CrossRef] [PubMed]

60. Latgé, J.P. The cell wall: A carbohydrate armour for the fungal cell. Mol. Microbiol. 2007, 66, $279-290$. [CrossRef] [PubMed]

61. Planas, A. Bacterial 1,3-1,4-beta-glucanases: Structure, function and protein engineering. Biochim. Biophys. Acta Protein Struct. Molec. Enzyme 2000, 1543, 361-382. [CrossRef]

62. Mardanova, A.M.; Hadieva, G.F.; Lutfullin, M.T.; Khilyas, I.V.; Minnullina, L.F.; Gilyazeva, A.G.; Bogomolnaya, L.M.; Sharipova, M.R. Bacillus subtilis strains with antifungal activity against the phytopathogenic fungi. Agric. Sci. 2017, 8, 1-20.

63. Abdallah, R.A.B.; Stedel, C.; Garagounis, C.; Nefzi, A.; Jabnoun-Khiareddine, H.; Papadopoulou, K.K.; Daami-Remadi, M. Involvement of lipopeptide antibiotics and chitinase genes and induction of host defense in suppression of Fusarium wilt by endophytic Bacillus spp. in tomato. Crop Prot. 2017, 99, 45-58. [CrossRef]

64. Islam, M.R.; Jeong, Y.T.; Lee, Y.S.; Song, C.H. Isolation and identification of antifungal compounds from Bacillus subtilis C9 inhibiting the growth of plant pathogenic fungi. Mycobiology 2012, 40, 59-66. [CrossRef]

65. Khan, A.; Singh, P.; Srivastava, A. Synthesis, nature and utility of universal iron chelator-siderophore: A review. Microbiol. Res. 2018, 212-213, 103-111. [CrossRef] [PubMed]

66. Saha, M.; Sarkar, S.; Sarkar, B.; Sharma, B.K.; Bhattacharjee, S.; Tribedi, P. Microbial siderophores and their potential applications: A review. Environ. Sci. Pollut. Res. Int. 2016, 23, 3984-3999. [CrossRef] [PubMed]

67. Ahmed, E.; Holmström, S.J. Siderophores in environmental research: Roles and applications. Microb. Biotechnol. 2014, 7, 196-208. [CrossRef] [PubMed]

68. Hertlein, G.; Müller, S.; Garcia-Gonzalez, E.; Poppinga, L.; Süssmuth, R.D.; Genersch, E. Production of the catechol type siderophore bacillibactin by the honey bee pathogen Paenibacillus larvae. PLoS ONE 2014, 9, e108272. [CrossRef] [PubMed]

69. Khan, A.; Doshi, H.V.; Thakur, M.C. Bacillus spp.: A Prolific Siderophore Producer. In Bacilli and Agrobiotechnology; Islam, M., Rahman, M., Pandey, P., Jha, C., Aeron, A., Eds.; Springer: Cham, Germany, 2016; pp. 309-323.

70. Bjelić, D.; Marinković, J.; Tintor, B.; Mrkovački, N. Antifungal and plant growth promoting activities of indigenous rhizobacteria isolated from maize (Zea mays L.) rhizosphere. Commun. Soil Sci. Plant Anal. 2018, 49, 88-98. [CrossRef]

71. Pieterse, C.M.; Zamioudis, C.; Berendsen, R.L.; Weller, D.M.; Van Wees, S.C.; Bakker, P.A. Induced systemic resistance by beneficial microbes. Annu. Rev. Phytopathol. 2014, 52, 347-375. [CrossRef]

72. Van Wees, S.C.; De Swart, E.A.; Van Pelt, J.A.; Van Loon, L.C.; Pieterse, C.M. Enhancement of induced disease resistance by simultaneous activation of salicylate- and jasmonate-dependent defense pathways in Arabidopsis thaliana. Proc. Natl. Acad. Sci. USA 2000, 97, 8711-8716. [CrossRef]

73. Li, C.; Hu, W.; Pan, B.; Liu, Y.; Yuan, S.; Ding, Y.; Li, R.; Zheng, X.; Shen, B.; Shen, Q. Rhizobacterium Bacillus amyloliquefaciens strain SQRT3-mediated induced systemic resistance controls bacterial wilt of tomato. Pedosphere 2017, 27, 1135-1146. [CrossRef]

74. Choudhary, D.K.; Johri, B.N. Interactions of Bacillus spp. and plants-with special reference to induced systemic resistance (ISR). Microbiol. Res. 2009, 164, 493-513. [CrossRef]

75. Niu, D.; Wang, X.; Wang, Y.; Song, X.; Wang, J.; Guo, J.; Zhao, H. Bacillus cereus AR156 activates PAMP-triggered immunity and induces a systemic acquired resistance through a NPR1-and SA-dependent signaling pathway. Biochem. Biophys. Res. Commun. 2016, 469, 120-125. [CrossRef] 
76. Singh, S.K.; Pathak, R.; Choudhary, V. Plant Growth-Promoting Rhizobacteria-Mediated Acquired Systemic Resistance in Plants Against Pest and Diseases. In Microbial-Mediated Induced Systemic Resistance in Plants; Choudhary, D.K., Varma, A., Eds.; Springer: Singapore, 2016; pp. 125-134.

77. Kloepper, J.W.; Ryu, C.M.; Zhang, S. Induced systemic resistance and promotion of plant growth by Bacillus spp. Phytopathology 2004, 94, 1259-1266. [CrossRef] [PubMed]

78. Beris, D.; Theologidis, I.; Skandalis, N.; Vassilakos, N. Bacillus amyloliquefaciens strain MBI600 induces salicylic acid dependent resistance in tomato plants against Tomato spotted wilt virus and Potato virus Y. Sci. Rep. 2018, 8, 10320. [CrossRef]

79. Nie, P.; Li, X.; Wang, S.; Guo, J.; Zhao, H.; Niu, D. Induced systemic resistance against Botrytis cinerea by Bacillus cereus AR156 through a JA/ET- and NPR1-dependent signaling pathway and activates pamp-triggered immunity in Arabidopsis. Front. Plant Sci. 2017, 8, 238. [CrossRef]

80. Spaepen, S.; Vanderleyden, J.; Remans, R. Indole-3-acetic acid in microbial and microorganism-plant signalling. FEMS Microbiol. Rev. 2007, 31, 425-448. [CrossRef] [PubMed]

81. Choi, H.K.; Song, G.C.; Yi, H.S.; Ryu, C.M. Field evaluation of the bacterial volatile derivative 3-pentanol in priming for induced resistance in pepper. J. Chem. Ecol. 2014, 40, 882-892. [CrossRef] [PubMed]

82. Kildea, S.; Ransbortyn, V.; Khan, M.R.; Fagan, B.; Leonard, G.; Mullins, E.; Doohan, F.M. Bacillus megaterium shows potential for the biocontrol of septoria tritici blotch of wheat. Biol. Control 2008, 47, 37-45. [CrossRef]

83. Gond, S.K.; Bergen, M.S.; Torres, M.S.; White, J.F. Endophytic Bacillus spp. produce antifungal lipopeptides and induce host defence gene expression in maize. Microbiol. Res. 2015, 172, 79-87. [CrossRef]

84. Chowdappa, P.; Kumar, S.M.; Lakshmi, M.J.; Mohan, S.P.; Upreti, K.K. Growth stimulation and induction of systemic resistance in tomato against early and late blight by Bacillus subtilis OTPB1 or Trichoderma harzianum OTPB3. Biol. Control 2013, 65, 109-117. [CrossRef]

85. Rais, A.; Jabeen, Z.; Shair, F.; Hafeez, F.Y.; Hassan, M.N. Bacillus spp., a bio-control agent enhances the activity of antioxidant defense enzymes in rice against Pyricularia oryzae. PLoS ONE 2017, 12, e0187412. [CrossRef]

86. Jayapala, N.; Mallikarjunaiah, N.; Puttaswamy, H.; Gavirangappa, H.; Ramachandrappa, N.S. Rhizobacteria Bacillus spp. induce resistance against anthracnose disease in chili (Capsicum annuum L.) through activating host defense response. Egypt. J. Biol. Pest Control 2019, 29, 45. [CrossRef]

87. Jain, S.; Vaishnav, A.; Kumari, S.; Varma, T.; Tuteja, N.; Kumar Choudhary, D. Chitinolytic Bacillus-mediated induction of jasmonic acid and defense-related proteins in soybean (Glycine max L. Merrill) plant against Rhizoctonia solani and Fusarium oxysporum. J. Plant Growth Regul. 2017, 36, 200-214. [CrossRef]

88. Chen, F.; Wang, M.; Zheng, Y.; Luo, J.; Yang, X.; Wang, X. Quantitative changes of plant defense enzymes and phytohormone in biocontrol of cucumber Fusarium wilt by Bacillus subtilis B579. World J. Microbiol. Biotechnol. 2010, 26, 675-684. [CrossRef]

89. Nandeeshkumar, P.; Ramachandrakini, K.; Prakash, H.S.; Niranjana, S.R.; Shekar Shetty, H. Induction of resistance against downy mildew on sunflower by rhizobacteria. J. Plant Interact. 2008, 3, 255-262. [CrossRef]

90. Cabello, P.; Roldán, M.D.; Castillo, F.; Moreno-Vivián, C. Nitrogen Cycle. In Encyclopedia of Microbiology; Schaechter, M., Ed.; Academic Press: London, UK, 2009; pp. 299-321.

91. Mus, F.; Crook, M.B.; Garcia, K.; Garcia Costas, A.; Geddes, B.A.; Kouri, E.D.; Paramasivan, P.; Ryu, M.-H.; Oldroyd, G.E.D.; Poole, P.S.; et al. Symbiotic nitrogen fixation and the challenges to its extension to nonlegumes. Appl. Environ. Microbiol. 2016, 82, 3698-3710. [CrossRef] [PubMed]

92. Rascio, N.; La Rocca, N. Biological Nitrogen Fixation. In Encyclopedia of Ecology; Fath, B., Ed.; Elsevier: Amsterdam, The Netherlands, 2013; pp. 264-279.

93. Kuan, K.B.; Othman, R.; Abdul Rahim, K.; Shamsuddin, Z.H. Plant growth-promoting rhizobacteria inoculation to enhance vegetative growth, nitrogen fixation and nitrogen remobilisation of maize under greenhouse conditions. PLoS ONE 2016, 11, e0152478. [CrossRef] [PubMed]

94. Ding, Y.; Wang, J.; Liu, Y.; Chen, S. Isolation and identification of nitrogen-fixing bacilli from plant rhizospheres in Beijing region. J. Appl. Microbiol. 2005, 99, 1271-1281. [CrossRef]

95. Xie, G.H.; Su, B.L.; Cui, Z.J. Isolation and identification of N2-fixing strains of Bacillus in rice rhizosphere of the Yangtze River valley. Acta Microbiol. Sin. 1998, 38, 480-483.

96. Szilagyi-Zecchin, V.J.; Ikeda, A.C.; Hungria, M.; Adamoski, D.; Kava-Cordeiro, V.K.; Glienke, C.; Galli-Terasawa, L.V. Identification and characterization of endophytic bacteria from corn (Zea mays L.) roots with biotechnological potential in agriculture. AMB Express 2014, 4, 1-9. [CrossRef] 
97. Ikeda, S.; Tokida, T.; Nakamura, H.; Sakai, H.; Usui, Y.; Okubo, T.; Tago, K.; Hayashi, K.; Sekiyama, Y.; Ono, H.; et al. Characterization of leaf blade- and leaf sheath-associated bacterial communities and assessment of their responses to environmental changes in $\mathrm{CO}_{2}$, temperature, and nitrogen levels under field conditions. Microbes Environ. 2015, 30, 51-62. [CrossRef]

98. Bahadir, P.S.; Liaqat, F.; Eltem, R. Plant growth promoting properties of phosphate solubilizing Bacillus species isolated from the Aegean Region of Turkey. Turk. J. Bot. 2018, 42, 1-14. [CrossRef]

99. Garcia-Lopez, A.M.; Delgado, A. Effect of Bacillus subtilis on phosphorus uptake by cucumber as affected by iron oxides and the solubility of the phosphorus source. Agric. Food Sci. 2016, 25, 216-224. [CrossRef]

100. Radhakrishnan, R.; Lee, I.J. Gibberellins producing Bacillus methylotrophicus KE2 supports plant growth and enhances nutritional metabolites and food values of lettuce. Plant Physiol. Biochem. 2016, 109, 181-189. [CrossRef] [PubMed]

101. Arkhipova, T.N.; Veselov, S.U.; Melentiev, A.I.; Martynenko, E.V.; Kudoyarova, G.R. Ability of bacterium Bacillus subtilis to produce cytokinins and to influence the growth and endogenous hormone content of lettuce plants. Plant Soil 2005, 272, 201-209. [CrossRef]

102. Ortíz-Castro, R.; Valencia-Cantero, E.; López-Bucio, J. Plant growth promotion by Bacillus megaterium involves cytokinin signaling. Plant Signal. Behav. 2008, 3, 263-265. [CrossRef]

103. Naz, I.; Bano, A.; Ul-Hassan, T. Isolation of phytohormones producing plant growth promoting rhizobacteria from weeds growing in Khewra salt range, Pakistan and their implication in providing salt tolerance to Glycine max L. Afr. J. Biotechnol. 2009, 8, 5762-5766.

104. Xu, M.; Sheng, J.; Chen, L.; Men, Y.; Gan, L.; Guo, S.; Shen, L. Bacterial community compositions of tomato (Lycopersicum esculentum Mill.) seeds and plant growth promoting activity of ACC deaminase producing Bacillus subtilis (HYT-12-1) on tomato seedlings. World J. Microbiol. Biotechnol. 2014, 30, 835-845. [CrossRef] [PubMed]

105. Park, Y.-G.; Mun, B.-G.; Kang, S.-M.; Hussain, A.; Shahzad, R.; Seo, C.-W.; Kim, A.-Y.; Lee, S.-U.; Oh, K.Y.; Lee, D.Y.; et al. Bacillus aryabhattai SRB02 tolerates oxidative and nitrosative stress and promotes the growth of soybean by modulating the production of phytohormones. PLoS ONE 2017, 12, e0173203. [CrossRef]

106. Shahzad, R.; Khan, A.L.; Bilal, S.; Waqas, M.; Kang, S.-M.; Lee, I.-J. Inoculation of abscisic acid-producing endophytic bacteria enhances salinity stress tolerance in Oryza sativa. Environ. Exp. Bot. 2017, 136, 68-77. [CrossRef]

107. Shen, J.; Yuan, L.; Zhang, J.; Li, H.; Bai, Z.; Chen, X.; Zhang, W.; Zhang, F. Phosphorus dynamics: From soil to plant. Plant Physiol. 2011, 156, 997-1005. [CrossRef]

108. Rodríguez, H.; Fraga, R. Phosphate solubilizing bacteria and their role in plant growth promotion. Biotechnol. Adv. 1999, 17, 319-339. [CrossRef]

109. Granada, C.E.; Passaglia, L.; de Souza, E.M.; Sperotto, R.A. Is phosphate solubilization the forgotten child of plant growth-promoting rhizobacteria? Front. Microbiol. 2018, 9, 2054. [CrossRef]

110. Sharma, S.B.; Sayyed, R.Z.; Trivedi, M.H.; Gobi, T.A. Phosphate solubilizing microbes: Sustainable approach for managing phosphorus deficiency in agricultural soils. Springerplus 2013, 2, 587-600. [CrossRef] [PubMed]

111. Richardson, A.E.; Simpson, R.J. Soil microorganisms mediating phosphorus availability. Plant Physiol. 2011, 156, 989-996. [CrossRef]

112. Saeid, A.; Prochownik, E.; Dobrowolska-Iwanek, J. Phosphorus solubilization by Bacillus species. Molecules 2018, 23, 2897. [CrossRef]

113. Tao, G.C.; Tian, S.J.; Cai, M.Y.; Xie, G.H. Phosphate-solubilizing and -mineralizing abilities of bacteria isolated from soils. Pedosphere 2008, 18, 515-523. [CrossRef]

114. Woodward, A.W.; Bartel, B. Auxin: Regulation, action, and interaction. Ann. Bot. 2005, 95, 707-735. [CrossRef] [PubMed]

115. Khalid, A.; Arshad, M.; Zahir, Z.A. Screening plant growth promoting rhizobacteria for improving growth and yield of wheat. J. Appl. Microbiol. 2004, 96, 473-480. [CrossRef] [PubMed]

116. Bhutani, N.; Maheshwari, R.; Negi, M.; Suneja, P. Optimization of IAA production by endophytic Bacillus spp. from Vigna radiata for their potential use as plant growth promoters. Isr. J. Plant Sci. 2018, 65, 83-96. [CrossRef]

117. Ambreetha, S.; Chinnadurai, C.; Marimuthu, P.; Balachandar, D. Plant-associated Bacillus modulates the expression of auxin-responsive genes of rice and modifies the root architecture. Rhizosphere 2018, 5, 57-66. [CrossRef] 
118. Gutierrez-Manero, F.J.; Ramos-Solano, B.; Probanza, A.; Mehouachi, J.R.; Tadeo, F.; Talon, M. The plant-growth-promoting rhizobacteria Bacillus pumilus and Bacillus licheniformis produce high amounts of physiologically active gibberellins. Physiol. Plant 2001, 111, 206-211. [CrossRef]

119. Barea, J.M.; Navaro, E.; Montoya, E. Production of plant growth regulators by rhizosphere phosphate-solubilizing bacteria. J. Appl. Bacteriol. 1976, 40, 129-134. [CrossRef]

120. Glick, B.R. Bacteria with ACC deaminase can promote plant growth and help to feed the world. Microbiol. Res. 2014, 169, 30-39. [CrossRef]

121. Gamalero, E.; Glick, B.R. Bacterial modulation of plant ethylene levels. Plant Physiol. 2015, 169, $13-22$. [CrossRef]

122. Glick, B.R.; Todorovic, B.; Czarny, J.; Cheng, Z.; Duan, J.; McConkey, B. Promotion of plant growth by bacterial ACC deaminase. Crit. Rev. Plant Sci. 2007, 26, 227-242. [CrossRef]

123. Khan, A.L.; Halo, B.A.; Elyassi, A.; Ali, S.; Al-Hosni, K.; Hussain, J.; Al-Harrasi, A.; Lee, I.-J. Indole acetic acid and ACC deaminase from endophytic bacteria improves the growth of Solanum lycopersicum. Electron. J. Biotechnol. 2016, 21, 58-64.

124. Nascimento, F.X.; Rossi, M.J.; Soares, C.R.; McConkey, B.J.; Glick, B.R. New insights into 1-aminocyclopropane-1-carboxylate (ACC) deaminase phylogeny, evolution and ecological significance. PLoS ONE 2014, 9, e99168. [CrossRef] [PubMed]

125. Porwal, S.; Lal, S.; Cheema, S.; Kalia, V.C. Phylogeny in aid of the present and novel microbial lineages: Diversity in Bacillus. PLoS ONE 2009, 4, e4438. [CrossRef] [PubMed]

126. Sicuia, O.A.; Constantinscu, F.; Cornea, C.P. Biodiversity of Bacillus subtilis group and beneficial traits of Bacillus species useful in plant protection. Rom. Biotechnol. Lett. 2015, 20, 10737-10750.

127. Abedinzadeh, M.; Etesami, H.; Alikhani, H.A. Characterization of rhizosphere and endophytic bacteria from roots of maize (Zea mays L.) plant irrigated with wastewater with biotechnological potential in agriculture. Biotechnol. Rep. 2019, 21, e00305. [CrossRef]

128. Gao, S.; Wu, H.; Yu, X.; Qian, L.; Gao, X. Swarming motility plays the major role in migration during tomato root colonization by Bacillus subtilis SWR01. Biol. Control. 2016, 98, 11-17. [CrossRef]

129. Beauregard, P.B.; Chai, Y.R.; Vlamakis, H.; Losick, R.; Kolter, R. Bacillus subtilis biofilm induction by plant polysaccharides. Proc. Natl. Acad. Sci. USA 2013, 110, E1621-E1630. [CrossRef]

130. Zhang, N.; Yang, D.; Wang, D.; Miao, Y.; Shao, J.; Zhou, X.; Xu, Z.; Li, Q.; Feng, H.; Li, S.; et al. Whole transcriptomic analysis of the plant-beneficial rhizobacterium Bacillus amyloliquefaciens SQR9 during enhanced biofilm formation regulated by maize root exudates. BMC Genom. 2015, 16, 685. [CrossRef] [PubMed]

131. Martins, S.J.; Medeiros, F.H.V.; Lakshmanan, V.; Bais, H.P. Impact of seed exudates on growth and biofilm formation of Bacillus amyloliquefaciens ALB629 in common bean. Front. Microbiol. 2018, 8, 2631. [CrossRef] [PubMed]

132. Olanrewaju, O.S.; Ayangbenro, A.S.; Glick, B.R.; Babalola, O.O. Plant health: Feedback effect of root exudates-rhizobiome interactions. Appl. Microbiol. Biotechnol. 2019, 103, 1155-1166. [CrossRef] [PubMed]

133. Stamenkovic Stojanovic, S.; Karabegovic, I.; Beskoski, V.; Nikolic, N.; Lazic, M. Bacillus based microbial formulations: Optimization of the production process. Hem. Ind. 2019, 73, 169-182. [CrossRef]

134. Rosenberg, G.; Steinberg, N.; Oppenheimer-Shaanan, Y.; Olender, T.; Doron, S.; Ben-Ari, J.; Sirota-Madi, A.; Bloom-Ackermann, Z.; Kolodkin-Ga, I. Not so simple, not so subtle: The interspecies competition between Bacillus simplex and Bacillus subtilis and its impact on the evolution of biofilms. NPJ Biofilms Microb. 2016, 2, 15027. [CrossRef] [PubMed]

135. Monteiro, S.M.S.; Clemente, J.J.; Carrondo, M.J.T.; Cunha, A.E. Enhanced spore production of Bacillus subtilis grown in a chemically defined medium. Adv. Microbiol. 2014, 4, 444-454. [CrossRef]

(C) 2020 by the authors. Licensee MDPI, Basel, Switzerland. This article is an open access article distributed under the terms and conditions of the Creative Commons Attribution (CC BY) license (http://creativecommons.org/licenses/by/4.0/). 